\title{
Three Novel Mutations in CYB5R3 Gene Causing NADH-cytochrome b5 Reductase Enzyme Deficiency Leads to Recessive Congenital Methaemoglobinemia
}

\section{Anuradha Deorukhkar}

National Institute of Immunohaematology Hemoglobinopathies Department

\section{Anuja KULKARNI}

National Institute of Immunohaematology Hemoglobinopathies Department

Prabhakar S Kedar ( $\nabla$ kedarps2002@yahoo.com )

National Institute of Immunohaematology https://orcid.org/0000-0003-3509-2913

\section{Research Article}

Keywords: CYB5R3, DIA1, Methaemoglobinemia, Neurological impairment, Developmental disorders, Inherited recessive diseases, RCM I and II

Posted Date: August 4th, 2021

DOl: https://doi.org/10.21203/rs.3.rs-732442/v1

License: (c) (1) This work is licensed under a Creative Commons Attribution 4.0 International License. Read Full License

Version of Record: A version of this preprint was published at Molecular Biology Reports on January 22nd, 2022. See the published version at https://doi.org/10.1007/s11033-021-07031-3. 


\section{Abstract}

Two types of recessive congenital methaemoglobinemia (RCM) is caused by NADH-dependent cytochrome b5 reductase enzyme deficiency encoded by CYB5R3 gene. RCM-I is characterized by higher methaemoglobin levels ( $>2 \mathrm{~g} / \mathrm{dL}$ ), causing only cyanosis, whereas RCMR-II is associated with cyanosis with neurological impairment. The present study discovered three novel homozygous pathogenic variants of $C Y B 5 R 3$ causing RCM I and II in four unrelated Indian patients. In patient- 1 and patient-2 of are of RCM type I caused due to novel c.175C>T (p.Arg59Cys) and other reported c.469T>C (p.Phe157Ser) missense pathogenic variants respectively, whereas patient-3 and patient-4 presented with the RCM type II are related to developmental delay with cyanosis since birth due to a novel homozygous (g.25679_25679delA) splice-site deletion and novel homozygous c.824_825insC (p.Pro278ThrfsTer367) single nucleotide insertion. The CYB5R3 transcript levels were estimated by qRT-PCR in the splice-site deletion, which was 0.33 fold of normal healthy control. The insertion of nucleotide $C$ resulted in a frameshift of termination codon are associated with neurological impairment. This study can help to conduct genetic counselling and, subsequently, prenatal diagnosis of high-risk genetic disorders.

\section{Introduction}

The genetic aberrations in the CYB5R3 gene (OMIM 613213) result in Recessive Congenital Methaemoglobinemia (RCM) (OMIM 250800), a recessively inherited disorder caused by the partially nonfunctional enzyme or complete loss of enzyme activity of NADH-dependent cytochrome B5 reductase (NADH-CYB5R) [1]. RCM is classified into two categories, demonstrating specific symptoms like cyanosis and shortness of breath related to hypoxia in tissues due to increased methaemoglobin levels categorized as type I RCM. Type II (generalized) RCM is characterized by cyanosis along with severe neurological disorders, brain dysfunction, dystonia, choreoathetosis, microcephaly, intellectual disability [2].

NADH-CYB5R (P00387) encoded by CYB5R3 plays an essential role in several oxidation-reduction reactions by transferring reducing equivalents NADH via NAD domain to the small molecules of cytochrome B5[3]. In RBCs, it converts methaemoglobin to the haemoglobin with heme-iron oxidized to the ferric $\left(\mathrm{Fe}^{3+}\right)$ state, back to the normal haemoglobin with $\mathrm{Fe}^{2+}$. Methaemoglobin is not an efficient oxygen carrier, which leads to a varying level of cyanosis, the normal level of methaemoglobin in whole blood is maintained at $\leq 1.5 \%$ or $\leq 0.2 \mathrm{~g} / \mathrm{dL}$ [4]. Enzyme activity of NADH-dependent cytochrome b5 reductase is within the range of $35 \pm 5 \mathrm{IU} / \mathrm{g}$ of $\mathrm{Hb}$. In other cells, NADH-CYB5R participates in fatty acid desaturation by providing the electrons to desaturate and the cholesterol biosynthesis pathway enzyme 4-methyl sterol oxidase, respectively [5]. Siendones et al. 2018 suggest CYB5R3 deficiency imparts pleiotropic tissue effects since it is an essential modulator of the intracellular NAD+/NADH ratio and therefore plays a vital role in aerobic metabolism and managing the oxidative stress of fibroblasts, neurons, and cardiomyocytes [6]. 
The CYB5R3 is a $31 \mathrm{~kb}$ gene also known as DIA (diaphorase gene). At contains nine exons and is located on chromosome 22. It codes for both soluble and microsomal forms of NADH-cytochrome b5 reductase [7]. The exon 2 encodes the sequence joining the membrane-binding domain with the catalytic domain of NAHD-CYB5R, suggesting that protein undergoes post-translational processing for producing two different forms of CYB5R [8-9]. The hydrophobic, non-polar C-terminal is later inserted into the lipid bilayer of the membranes of the golgi apparatus, microsomes, and mitochondria [10]. The membrane-bound enzyme is absent in RBCs due to the absence of these organelles[11]. A total of 75 pathogenic variants of CYB5R3 have been reported so far around the globe [12]. Here we describe the molecular basis of type I and type-II methemoglobinemia due to three novel mutations in the CYB5R3 gene causing NADHCYB5R deficiency in four patients from three distinct regions in India. We have also described the genotype-phenotype correlation of all three novel variants in the CYB5R3 gene.

\section{Methods}

\section{Patient History}

Patient-1and Patient-2: The two patients aged 15 years at the time of diagnosis referred to us from Uttar Pradesh (UP), North India, had cyanosis, blueish discoloration of lips, nails, no cardiac problem, no hepatosplenomegaly.

Patient-3: This patient is a 5-year-old male child from Uttar Pradesh, India, born to a consanguineous family was reported with cyanosis and severe neurological symptoms with a developmental delay, underdeveloped limbs leading to complete dependency. This patient has two healthy female siblings.

Patient-4: This patient is a 1-year male child born to a consanguineous family from the Nagpur region of Maharashtra, Central India, who was reported with cyanosis since birth with type II RCM symptoms such as a lack of social interactions indicating neurological symptoms.

\section{Biochemical, Haematological, and clinical assessment}

Routine haematological investigations were done as per Dacie \& Lewis [13]. The methaemoglobin level was evaluated by the potassium cyanide-ferricyanide method [14] modified from Evelyn and Malloy et al. method instantly after blood withdrawal, and informed consent from the parents of the patient was taken for further analysis [15]. The kinetic properties of NADH-cytochrome b5 reductase were determined in I.U./gm Hb by measuring the oxidation of $\mathrm{NADH}$ at $340 \mathrm{~nm}$ at $37^{\circ} \mathrm{C}$ for $10 \mathrm{~min}$. On a spectrophotometer (Analytical JENA, Germany). The reaction rate was determined from the linear portion of the curve, and rates were calculated using a linear regression model. Each reaction contained hemolysate, $2 \mathrm{mM}$ $\mathrm{K}_{3} \mathrm{Fe}(\mathrm{CN})_{6}, 1 \mathrm{mM}$ Tris- $\mathrm{HCl} \mathrm{pH}$ 8.0, 0.5mM EDTA and 0.2mM NADH [16]. All the analytical procedures and examinations were done as per the Helsinki Declaration of 1975. 


\section{Molecular characterization of RCM patients by Sanger sequencing of DNA and RNA.}

Genomic DNA was extracted from leukocytes using a Qiagen DNA extraction kit. Nine exons of the CYB5R3 (GenBank database accession IDs M28705 to M28713) were amplified, and the PCR amplicons were sequenced using a 3730 DNA analyzer and Big Dye Terminator v3.1 cycle sequencing kit (Applied Biosystems Inc.) [17](Mannino et al., 2018). RNA was extracted from whole blood lymphocytes by TRIzol ${ }^{\text {TM }}$ Reagent (Thermo Fischer Scientific). The quality of extracted RNA was checked using a Nanodrop spectrophotometer. The corresponding cDNA was synthesized from $30 \mathrm{ng}$ of total RNA using High-Capacity cDNA Reverse Transcription Kit (Applied Biosystems) and amplified using four sets of primers for Sanger sequencing 3'UTR from ATG (FI 5'ACGGTCTCGGCGGCGGC 3' and RI 5'GTACTTGATGTCCGGGCTCT 3'), (FII 5'CTGGTTCCTGTACAGTCTGC 3', RII 5'GTCCTTCTCGGTCTGGTT 3'), (F III 5'ATCCGACCTGACAAAAAGTC 3' RII 5'GCGTACTGGATCATGGGTG 3'), (FIV 5'CAGGAACAAACATTCTGCAC 3' RIV 5'TGCTCAGCCAGGTGATT3') up to 3'UTR.

\section{Gene expression of CYB5R3 by qRT-PCR}

The cDNA synthesized from $30 \mathrm{ng}$ of RNA was amplified with a Step-one real-time-PCR ABI 7700 Sequence Detector (Applied Biosystems, USA.) Applied Biosystems using TaqMan ${ }^{\mathrm{TM}}$ Gene Expression Master Mix and TaqMan ${ }^{\circledR}$ FAM-MGB probes for gene expression assays of $C Y B 5 R 3$. GAPDH was used as an internal control, and 15 healthy adults from the age group of 20 to 50 years were taken as normal control. The gene expression was estimated by $2^{-\Delta \Delta C T}$ method (Livac's methods) in comparative fold expression of $C Y B 5 R 3$ in RCM patients concerning healthy controls.

\section{Bioinformatics analysis}

Novel RCM variant was subjected to protein modeling using a Swiss PDB viewer. The pathogenic variants of $C Y B 5 R 3$ identified were tested for their effect on the structural and functional integrity of respective proteins using Grantham Score for change in polarity [18] SDM [19] PROVEAN [20], PolyPhen [21], and SIFT score [22]. The CYB5R3 frame-shift variant's protein modeling was performed with the ITASSER server [23].

\section{Results And Discussion}

Patient one and patient two from north India were referred to us with primary symptoms like cyanosis and bluish discoloration of lips and nails for the first time in 15 years. The haematological, biochemical, and molecular data are shown in Table-1 indicate the methaemoglobin level in Patient-1 and Patient-2 was $10.2 \mathrm{~g} / \mathrm{dL}$ and $14.75 \mathrm{~g} / \mathrm{dL}$ (Normal Methaemoglobin level $\leq 2 \mathrm{~g} / \mathrm{dL}$ ), whereas NADH-CYB5R activity was reduced to 10.5 and $8.02 \mathrm{IU} / \mathrm{g} \mathrm{Hb}$ (normal range: $35 \pm 5 \mathrm{IU} / \mathrm{g} \mathrm{Hb}$ ), respectively. Sanger sequencing of 
the exons of the CYB5R3 of Patient-1and Patient-2 led to the identification of novel substitution variants c.175C >T (p.Arg59Cys) in exon three and second variant c.470T>C (p.Phe157Ser) in exon 6 in of CYB5R3 gene. The protein modeling using the Swiss-PDB viewer predicted the putative formation of a new hydrogen bond of cysteine 59 with an amino acid from the $\beta$ sheet in close proximity (Fig. 1 a). In this patient of p.Phe157Ser, aliphatic amino acid replaced the aromatic amino acid (Fig. 1 b). These protein conformation changes have likely changed NADH-cytochrome b5 reductase activity in RBC, causing only cyanosis. Grantham score prediction for p.Arg59Cys and p.Phe157Ser is of the C65 category assumed to be significantly affected protein function of NADH-CYB5R. Bioinformatics tools such as Provean, SIFT, PolyPhen algorithms have also predicted c.175C >T (p.Arg59Cys) and c.470T>C (p.Phe157Ser) as most likely pathogenic variants (Table-1).

The patient-3 presented with developmental delay along with cyanosis at the age of 5 years and showed a methaemoglobin level of $63 \mathrm{~g} / \mathrm{dL}$ and having NADH-CYB5R activity of $9.3 \mathrm{lU} / \mathrm{g} \mathrm{Hb}$. The heterozygous mother presented a methaemoglobin level of $12.33 \mathrm{~g} / \mathrm{dL}$ and reduced NADH-CYB5R activity $(20.79 \mathrm{IU} / \mathrm{g}$ $\mathrm{Hb}$ ), while the heterozygous father showed $3.27 \%$ methaemoglobin level and reduced NADH-CYB5R activity (18.03 IU/g Hb) Table-1. Molecular characterisation of patient-3 showed homozygous variant g.25679_25679delA at the splice site in IVS 8 with deletion of A from Splice acceptor site AG_3'. Both maternal and paternal DNA showed a heterozygous form of an identified pathogenic variant (Fig. 2a). The resultant transcript sequence of g.25679_25679delA was determined by cDNA sequencing. The junction sequence of exons 7 and 8 , which was anticipated to be affected due to splice-site deletion when the cDNA was amplified, demonstrated a typical sequence (Fig. 2b). The potential alternative splice-site was analyzed for splice site variant in patient-3 using Human Splicing Finder - Version 3.1. We further estimated the gene expression of $C Y B 5 R 3$ in propositus and parents. The $C Y B 5 R 3$ expression was found to be 0.33 folds in g.25679_25679delA novel homozygous variant when compared to normal healthy control, indicating low transcript levels owing to Nonsense-mediated mRNA decay (NMD) mutant transcripts [24]. Mother and Father of patient-3with heterozygous g.25679_25679delA showed 3.4 folds and 5.73 folds of the transcript. The absence of 1 out of 2 normal alleles of CYB5R3 might have triggered NMD of mutant transcripts in heterozygous parents leading to insufficient CYB5R3 mRNA, which resulted in over-expression of $C Y B 5 R 3$ in Type II heterozygous parents. The mother was reported to have incidences of mild cyanosis and difficulties in breathing in contrast to the asymptomatic father of patient-3. Although methaemoglobin levels are recommended in the normal range of 0.0-1.5 g/dL, unprecedented levels of cyanosis cannot be identified below the concentration of $10 \mathrm{~g} / \mathrm{dL}$. Hence, heterozygous patients with an identical variant have a variable presentation of phenotype.

The patient-4 was a one-year-old child with RCM II presentation, was found to have a methaemoglobin level of $15.93 \mathrm{~g} / \mathrm{dL}$ and NADH-CYB5R activity of $6.02 \mathrm{lU} / \mathrm{g} \mathrm{Hb}$. His heterozygous mother presented a methaemoglobin level of $5.34 \mathrm{~g} / \mathrm{dL}$, and NADH-CYB5R activity was $15.78 \mathrm{IU} / \mathrm{g} \mathrm{Hb}$, while the heterozygous father showed $6.05 \mathrm{~g} / \mathrm{dL}$ methaemoglobin level and $14.07 \mathrm{IU} / \mathrm{g} \mathrm{Hb}$ NADH-CYB5R activity, and both were reported to be asymptomatic patients. The exon sequencing of the patient- 4 presented with Type II RCM symptoms identified novel homozygous variant, c.824_825insC [(p.Pro278ThrfsTer367)] in CYB5R3 gene. Both maternal and paternal DNA contains a heterozygous form of the identified frame-shift variant (Fig. 
2c). The single nucleotide insertion in the coding sequence of $C Y B 5 R 3$ resulted in a frame-shift variant starting from the replacement of Proline at 278 positions to Threonine substitution of 24 amino acids at 3 'end and shift of the termination codon adding 66 amino acids on 3 'end that culminated in extended protein (Fig.2C). The protein tertiary structure of p.Pro278ThrfsTer367 was predicted by I-TASSER (C-score -1.71 , Normal range -5 to 2 ) showed alteration in native secondary and tertiary conformation of protein from Amino acid 278 to 367 , severely affecting enzyme activity lead to Type II RCM. In clinical genetics, the first degree of consanguinity is defined as a union between a couple related as second cousins or closer from, equivalent to a coefficient of inbreeding in their progeny of $F>0.0156$ [25]. Parents of patient3 and patient- 4 with RCM II were reported to have third-degree consanguineous marriage in a community that practices austere endogamy spanning several generations. The presence of a homozygous pathogenic variant of $C Y B 5 R 3$ has again highlighted that consanguinity is the most acceptable factor in preserving the deleterious mutations in populations. These data are further elaborate that type I and II recessive methemoglobinemia $(R C M)$ is due to the instability of the NADH-dependent cytochrome b5 reductase enzyme regardless of the specific causative mutation to CYB5R3.

\section{Conclusion}

In this study we have identified three novel mutation in CYB5R3 gene causing very severe RCM due to NADH-CYB5R deficiencys in northen sothhern and western part of India, As India has ethnically and geographically diverse population with a high percentage of endogamous groups, there are chances of heavy load of genetic disorders. And, RCM is one of the most common genetic disorder with neurological impairment at risk. Extensive research is required to estimate of the distribution of pathogenic genetic variations in RCM genes in all groups. The Splice-site deletion g.25679_25679delA (n.634-2delA) at the splice-acceptor site interfered with the post-transcriptional splicing mechanism leading to CYB5R3 underexpression causing RCM II with severe neurological symptoms and single nucleotide insertion p.Pro278ThrfsTer367 resulted in a frame-shift of coding sequence affecting the original termination codon of $C Y B 5 R 3$ gene, causing structural and functional changes in native protein which affect neurological abnormalities. This study can help to conduct genetic counselling and, subsequently, prenatal diagnosis of high-risk genetic disorders.

\section{Declarations}

Funding information: This study was performed with the financial support of the Indian Council of Medical Research New Delhi and also supported by the Council of Scientific and Industrial Research (CSIR), India, Grant No. 27(0333)/18/EMR-II)

Conflict of interest: The authors declare that they have no conflict of interest.

Availability of data and material: All data generated or analyzed during this study are included in this published article. 
Authors' contributions P.K.: Conceived ideas and initiated the experimental work and supervision of work. , A.K.: Contributed to the findings of the work. , A.D.: Further experimental work and statistical analysis for expansion of idea were carried under the supervision of P.K., AD, and PK: Manuscript was written by A.D. in consultation with P.K.

Ethics approval: This study was approved by the Ethics Committee of the Institutional Ethical Committee of ICMR-National Institute of Immunohaematology, Mumbai. All procedures performed in studies involving human participants were per the ethical standards of the institutional review board of the Institute and with the 1964 Helsinki declaration and its later amendments or comparable ethical standards.

Consent to participate: Written informed consent was obtained from a legally authorized representative(s) for anonymized patient information to be published in this article.

Consent for publication: The written informed consent for publication was obtained.

\section{Acknowledgments}

We would like to thank patients and family members for their cooperation and participation in this study. This study was performed with the Indian Council of Medical Research New Delhi and the Council of Scientific and Industrial Research, India (CSIR) New Delhi for financial support.

\section{References}

1. Scott, E.M., Griffith, I. V., 1959. The enzymic defect of hereditary methemoglobinemia: diaphorase. BBA - Biochim. Biophys. Acta 34, 584-586. https://doi.org/10.1016/0006-3002(59)90324-5

2. Rehman, H.U., 2001. Methemoglobinemia. West. J. Med. 175, 193-196.

3. Elahian, F., Sepehrizadeh, Z., Moghimi, B., Mirzaei, S.A., 2014. Human cytochrome b5 reductase: Structure, function, and potential applications. Crit. Rev. Biotechnol. 34, 134-143. https://doi.org/10.3109/07388551.2012.732031

4. Skold, A., Cosco, D.L., Klein, R., 2011. Methemoglobinemia. South. Med. J. 104, 757-761. https://doi.org/10.1097/SMJ.0b013e318232139f

5. Fukushima, H., Grinstead, G.F., Gaylor, J.L., 1981. Total enzymic synthesis of cholesterol from lanosterol. Cytochrome b5-dependence of 4-methyl sterol oxidase. J. Biol. Chem. 256, 4822-4826.

6. Siendones, E., Ballesteros, M., Navas, P., 2018. Cellular and Molecular Mechanisms of Recessive Hereditary Methaemoglobinaemia Type II. J. Clin. Med. 7, 341. https://doi.org/10.3390/jcm7100341

7. Junien, C., Vibert, M., Weil, D., Van-Cong, N., Kaplan, J.-C., 1978. Assignment of NADH-cytochrome b5 reductase (DIA1 locus) to human chromosome 22. Hum. Genet. 42, 233-239. https://doi.org/10.1007/BF00291301

8. Choury, D., Leroux, A., Kaplan, J.C., 1981. Membrane-bound cytochrome b5 reductase (methemoglobin reductase) in human erythrocytes. Study in normal and methemoglobinemic 
subjects. J. Clin. Invest. 67, 149-155. https://doi.org/10.1172/JCl110007

9. Shunji, T., Yasushi, K., Yasuyuki, F., Toshitsugu, Y., Tadao, O., Yoshiyuki, S., 1989. The organization and the complete nucleotide sequence of the human NADH-cytochrome b5 reductase gene. Gene 80, 353-361. https://doi.org/10.1016/0378-1119(89)90299-0

10. Borgese, N., Gaetani, S., 1983. In vitro synthesis and post-translational insertion into microsomes of the integral membrane protein, NADH-cytochrome b5 oxidoreductase. EMBO J. 2, 1263-1269. https://doi.org/10.1002/j.1460-2075.1983.tb01579.x

11. Borgese, N., Meldolesi, J., 1980. Localization and biosynthesis of NADH-cytochrome b5 reductase, an integral membrane protein, in rat liver cells. I. Distribution of the enzyme activity in microsomes, mitochondria, and golgi complex. J. Cell Biol. 85, 501-515. https://doi.org/10.1083/jcb.85.3.501

12. Gupta, V., Kulkarni, A., Warang, P., Devendra, R., Chiddarwar, A., Kedar, P., 2020. Mutation update: Variants of the CYB5R3 gene in recessive congenital methemoglobinemia. Hum. Mutat. 41, 737748. https://doi.org/10.1002/humu.23973

13. Lewis, S.M., Barbara, J.B., Bates, I., 2006. Dacie and Lewis Practical Haematology, Eleventh. ed, Dacie and Lewis Practical Haematology. Elsevier. https://doi.org/10.1016/B0-443-06660-4/X5001-6

14. Bain, B.J., Bates, I., Laffan, M.A., Lewis, S.M., 2011. Basic hematological techniques.

15. Evelyn, K.A., Malloy, H.T., 1938. Microdetermination of oxyhemoglobin, methemoglobin, and sulfhemoglobin in a single sample of blood. J. Biol. Chem. 126, 655-662.

16. Fujii, S., Dale, G.L., Beutler, E., 1984. Glutathione-dependent protection against oxidative damage of the human red cell membrane. Blood 63, 1096-1101. https://doi.org/10.1182/blood.v63.5.1096.bloodjournal6351096

17. Mannino, E.A., Pluim, T., Wessler, J., Cho, M.T., Juusola, J., Schrier Vergano, S.A., 2018. Congenital methemoglobinemia type II in a 5-year-old boy. Clin. Case Reports 6, 170-178. https://doi.org/10.1002/ccr3.1310

18. Grantham, R., 1974. Amino acid difference formula to help explain protein evolution. Science 185, 862-4. https://doi.org/10.1126/science.185.4154.862

19. Pandurangan, A.P., Ochoa-Montaño, B., Ascher, D.B., Blundell, T.L., 2017. SDM: A server for predicting effects of mutations on protein stability. Nucleic Acids Res. 45, W229-W235. https://doi.org/10.1093/nar/gkx439

20. Choi, Y., Chan, A.P., 2015. PROVEAN web server: A tool to predict the functional effect of amino acid substitutions and indels. Bioinformatics 31, 2745-2747. https://doi.org/10.1093/bioinformatics/btv195

21. Adzhubei, I., Jordan, D.M., Sunyaev, S.R., 2013. Predicting Functional Effect of Human Missense Mutations Using PolyPhen-2. Curr. Protoc. Hum. Genet. 76, 7.20.1-7.20.41. https://doi.org/10.1002/0471142905.hg0720s76

22. Ng, P.C., Henikoff, S., 2003. SIFT: Predicting amino acid changes that affect protein function. Nucleic Acids Res. 31, 3812-3814. https://doi.org/10.1093/nar/gkg509 
23. Yang, J., Zhang, Y., 2015. I-TASSER server: new development for protein structure and function predictions. Nucleic Acids Res. 43, W174-W181. https://doi.org/10.1093/nar/gkv342

24. Brogna, S., Wen, J. 2009. Nonsense-mediated mRNA decay (NMD) mechanisms. Nat Struct Mol Biol 16, 107-113. https://doi.org/10.1038/nsmb.1550

25. Bittles, A., 2001. Consanguinity and its relevance to clinical genetics. Clin. Genet. 60, 89-98. https://doi.org/10.1034/j.1399-0004.2001.600201.x

\section{Tables}

Table 1: Haematological, Biochemical, and molecular data of three novel pathogenic variants of CYB5R3 gene causing Type-I and II Recessive Congenital Methaemoglobinemia (RCM). 


\begin{tabular}{|c|c|c|c|c|c|}
\hline Cases & $\begin{array}{l}\text { Normal } \\
\text { Range }\end{array}$ & I & II & III & IV \\
\hline Age & - & 15 years & 15 years & 5 years & 1 year \\
\hline Gender & - & M & M & M & $M$ \\
\hline Consanguinity & - & Yes & Yes & Yes & Yes \\
\hline \multicolumn{6}{|c|}{ Haematological, Biochemical and Molecular parameters } \\
\hline $\begin{array}{l}\text { Methaemoglobin } \\
\text { level (\%) }\end{array}$ & $<1.5$ & 10.29 & 14.75 & 63.32 & 15.93 \\
\hline $\begin{array}{l}\text { CYB5R Activity } \\
\mathrm{IU} / \mathrm{g} \mathrm{Hb}\end{array}$ & $35 \pm 5$ & 10.5 & 8.02 & 9.3 & 6.2 \\
\hline WBC $\left(X 10^{3} / \mu \mathrm{l}\right)$ & 4.5- 11.0 & 8.90 & 7.60 & 5.60 & 10.90 \\
\hline \multirow{2}{*}{$\operatorname{RBC}\left(X 10^{6} / \mu \mathrm{l}\right)$} & Men: 4.7- 6.1 & 7 & 6.02 & 5.58 & 5.19 \\
\hline & $\begin{array}{l}\text { Women: } 4.2 \\
-5.4\end{array}$ & & & & \\
\hline \multirow[t]{2}{*}{$\mathrm{HGB} \mathrm{g} / \mathrm{dl}$} & $\begin{array}{l}\text { Men: 13.5- } \\
17.5\end{array}$ & 19.6 & 15.6 & 11.3 & 12.3 \\
\hline & $\begin{array}{l}\text { Women:12.0- } \\
15.5\end{array}$ & & & & \\
\hline \multirow[t]{2}{*}{ HCT (\%) } & Men: 41-50 & 58.2 & 47.4 & 39 & 40 \\
\hline & $\begin{array}{l}\text { Women: } 36- \\
48\end{array}$ & & & & \\
\hline MCV (fl) & 80- 100 & 83.1 & 78.7 & 69.9 & 77.1 \\
\hline $\mathrm{MCH}(\mathrm{pg})$ & $29 \pm 2$ & 28 & 25.9 & 20.3 & 23.7 \\
\hline $\mathrm{MCHC}(\mathrm{g} / \mathrm{dl})$ & $34 \pm 2$ & 33.7 & 32.9 & 29 & 30.8 \\
\hline $\operatorname{PLT}\left(X 10^{3} / \mu \mathrm{l}\right)$ & $150-450$ & 190 & 211 & 390 & 462 \\
\hline RDW (\%) & $12.2-16.1$ & 13.6 & 14.4 & 22.4 & 12 \\
\hline RCM. & & Type I & Type I & Type II & Type II \\
\hline $\begin{array}{l}\text { Nucleotide } \\
\text { change }\end{array}$ & & c. $175 \mathrm{C}>\mathrm{T}$ & c. $470 T>C$ & $\begin{array}{l}\text { n.634- } \\
\text { 2delA }\end{array}$ & c.824_825insC \\
\hline \multirow{3}{*}{$\begin{array}{l}\text { Amino acid } \\
\text { Change }\end{array}$} & & p. & p. (Phe157Ser) & (Novel) & p.(Pro278Thr \\
\hline & & 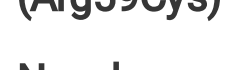 & (Reported) & & fsTer367) \\
\hline & & incos & & & (Novel) \\
\hline $\begin{array}{l}\text { Domain of } \\
\text { NADH-CYB5R }\end{array}$ & & FAD & Hinge region & NAD & NAD \\
\hline
\end{tabular}




\begin{tabular}{|c|c|c|}
\hline \multicolumn{3}{|c|}{ Pathogenicity predictions of $C Y B 5 R 3$ variants (UniProt accession ID: P00387) } \\
\hline $\begin{array}{l}\text { Grantham } \\
\text { Variation }\end{array}$ & 0.00 & 0.00 \\
\hline $\begin{array}{l}\text { Grantham } \\
\text { Deviation }\end{array}$ & 179.53 & 154.81 \\
\hline \multirow[t]{2}{*}{$\begin{array}{l}\text { Grantham } \\
\text { Prediction }\end{array}$} & $\begin{array}{l}\text { C65-most } \\
\text { likely to } \\
\text { interfere }\end{array}$ & $\begin{array}{l}\text { C65-most likely to } \\
\text { interfere with the } \\
\text { function }\end{array}$ \\
\hline & $\begin{array}{l}\text { with the } \\
\text { function }\end{array}$ & \\
\hline Provean score & -6.88 & -7.27 \\
\hline $\begin{array}{l}\text { Provean } \\
\text { prediction }\end{array}$ & Deleterious & Deleterious \\
\hline SIFT Score & 0.005 & 0 \\
\hline $\begin{array}{l}\text { SIFT Prediction } \\
\text { (cutoff }=0.05 \text { ) }\end{array}$ & Damaging & Damaging \\
\hline PolyPhen Score & 1 & 1 \\
\hline $\begin{array}{l}\text { PolyPhen } \\
\text { Prediction }\end{array}$ & $\begin{array}{l}\text { Probably } \\
\text { Damaging }\end{array}$ & $\begin{array}{l}\text { Probably } \\
\text { Damaging }\end{array}$ \\
\hline
\end{tabular}

Note: METH HB-Methaemoglobin, WBC: White Blood Cells, RBC; Red Blood Cells, PLT; Platelet, HGB; Haemoglobin, HCT; Haematocrit, MCV; Mean Corpuscular Volume, $\mathrm{MCH}$; mean Corpuscular Haemoglobin, MCHC; Mean Corpuscular Haemoglobin Concentration, RDW; Red Cell Distribution Width

\section{Figures}


(a)

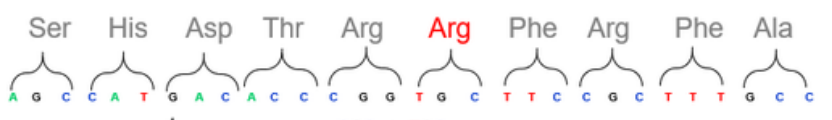
$\underset{\text { Arg }}{\mathrm{csc}} \overrightarrow{59} \underset{\text { cys }}{\mathrm{Tr}}$
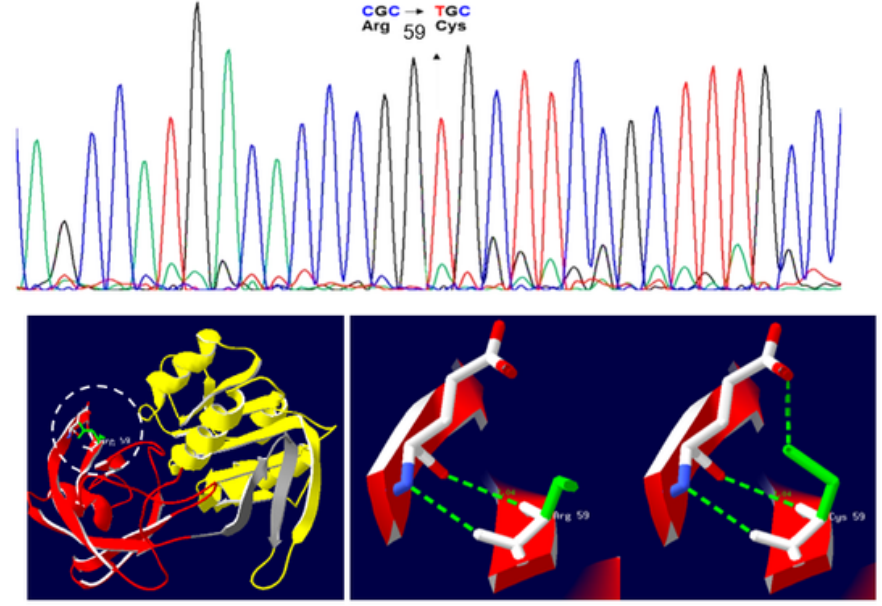

(b) Non-coding region
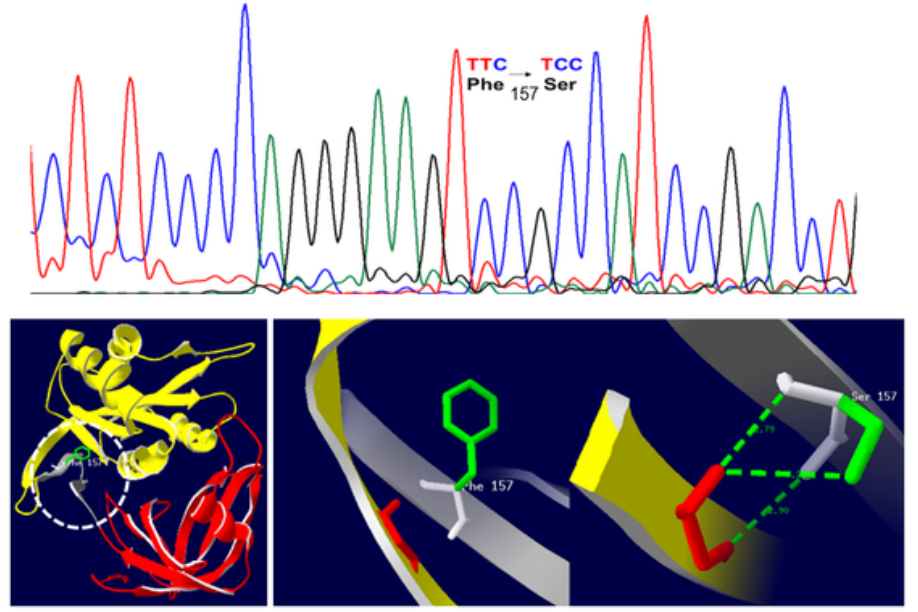

Figure 1

DNA sequencing chromatogram and Protein modeling of novel CYB5R3 pathogenic variants (a) Novel Variant in patient-1: c.175C >T (p.Arg59Cys) in exon 3 (b) Reported variant in patient-2: c.470T>C (p. Phe157Ser) in exon 6. 


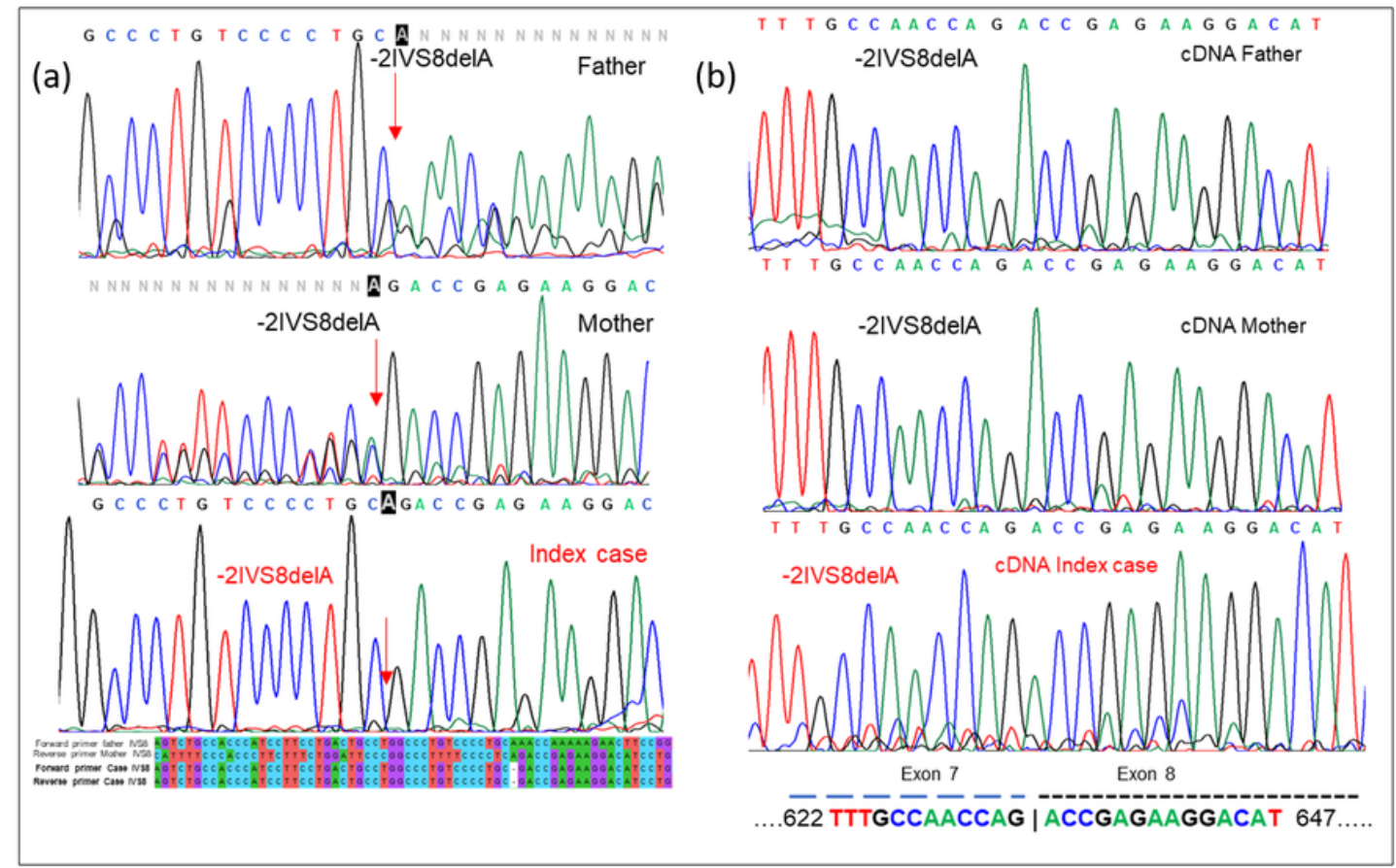

(c)

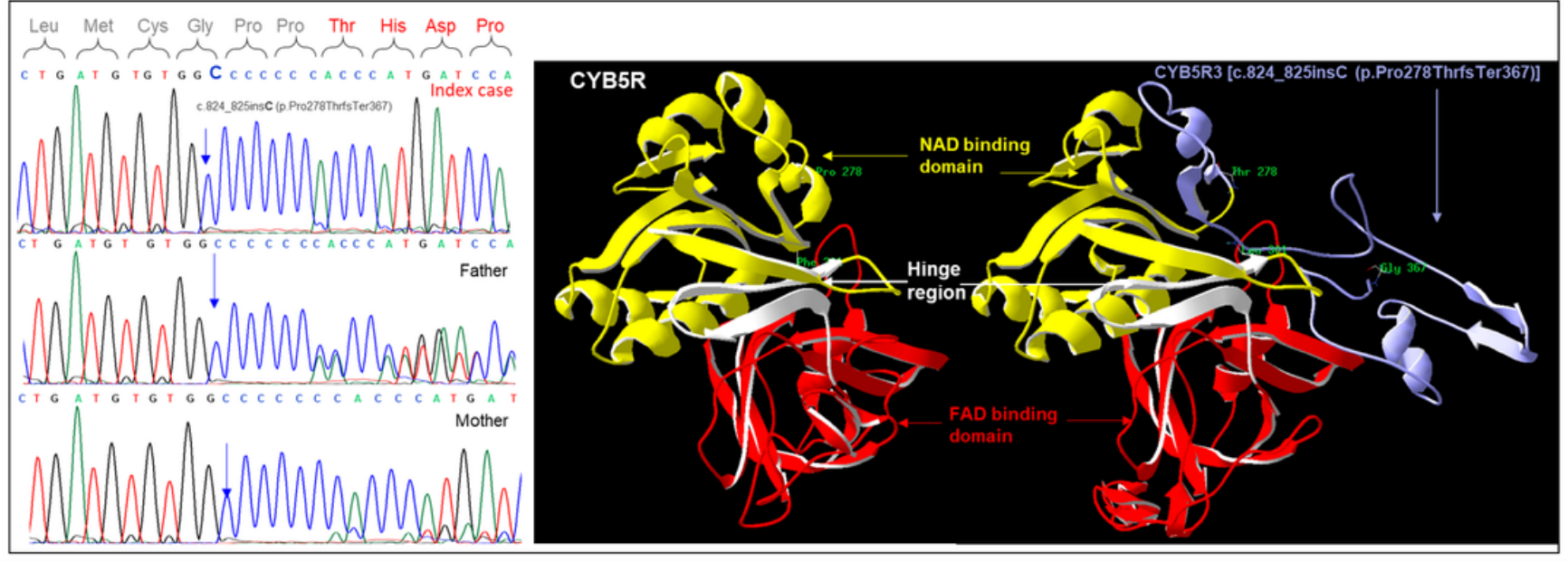

Figure 2

(a) DNA sequencing chromatogram of Novel Variant in patient-3: [g.25679_25679delA] (b) DNA ssequencing chromatogram of cDNA of propositus and parents with splice-site mutation n.634 -2delA (c) DNA sequencing chromatogram of the Novel homozygous variant of patient-4 with heterozygous parents and Protein modelling of novel variant: c.824_825insC [(p.Pro278ThrfsTer367)] 